\title{
Diet of Cattle Egrets (Bubulcus ibis ibis) in the flood valley of the Paraná River, northern Argentina
}

\author{
María de la Paz Ducommun ${ }^{a^{*}}$, Martín A. Quiroga ${ }^{a}$, Adolfo H. Beltzer ${ }^{a}$ and \\ Juan A. Schnack ${ }^{\mathbf{b}}$ \\ anstituto Nacional de Limnología (I.N.A.L.I., C.O.N.I.C.E.T. - U.N.L.), José Maciá 1933, (3016) \\ Santo Tomé, Santa Fe, Argentina \\ ${ }^{b}$ Facultad de Ciencias Naturales y Museo de La Plata (U.N.L.P.), Paseo del Bosque s/n, (1900) \\ La Plata, Buenos Aires, Argentina \\ *E-mail: ducommunpaz@yahoo.com.ar
}

\begin{abstract}
We analysed the feeding ecology of Cattle Egrets (Bubulcus ibis ibis) based on 30 individuals captured on the Carabajal island, Santa Fe, Argentina $\left(31^{\circ} 39^{\prime} \mathrm{S}, 60^{\circ} 42^{\prime} \mathrm{W}\right)$, determining the minimum sample, index of relative importance (IRI), size of prey, feeding efficiency, dietary selectivity, amplitude of the trophic niche, standardisation, circadian rhythm of feeding activity and habitat preference. The trophic spectrum was made up of 17 taxonomic entities, mainly insects $(I R I=15,000)$, among which orthopterans were the most numerous followed by spiders and amphibians $(I R I=250)$. The highest percentage of prey size was found in the interval $21-30 \mathrm{~mm}$. The amplitude of the trophic niche ranged between 1.98 and 3.45, and the feeding efficiency between 89 and $92 \%$. In relation to dietary selectivity, the correlation between abundance of prey in stomachs and abundance of prey in the study area yielded no significant results $\left(\mathrm{r}_{\mathrm{s}}=0.84, P>0.001\right)$. The rhythm of feeding activity responded to the bell-shaped model, which meant a peak in its feeding behaviour pattern at the noon hours. The pastures were the units of vegetation and environment selected more frequently.
\end{abstract}

Keywords: Cattle Egret, Bubulcus ibis ibis, Ardeidae, stomach content, feeding ecology, Paraná River, Santa Fe, Argentina

\section{INTRODUCTION}

The Cattle Egret (Bubulcus ibis ibis), originally from Africa and introduced in the New World, is distributed around North, Central and South America. In Argentina, it was observed for the first time in 1969 (Petracci and Delhey, 2005), nowadays it is a resident species distributed throughout the country including Tierra del Fuego, Georgias and Malvinas islands.

Although the preferred habitat of Cattle Egrets is the prairie, it also uses aquatic systems despite not depending on water to a great extent (Bó and Darrieu, 1993). Its name makes reference to the habit of being associated with cattle (and others grazing animals) while eating. The herons wait for insects and other preys that are scared away by these large animals while walking and hence are easier to detect and capture (Kaufman, 1996). This association appears to be an example of facultative commensalism (Rand, 1954; Heatwole, 1965).

Cattle egrets are gregarious birds that feed in flocks, breed colonially and establish large "roosting places" in permanent and temporary swamps or trees (de la
Peña, 1992). The demographic explosion and wide distribution of this species may be related to the increase of cattle-raising activities, in addition to the lack of competition with other species and their biotic potential (Bó and Darrieu, 1993).

In general, birds constitute a characteristic component of worldwide aquatic systems and they may be considered as indicators of the state of water bodies, their productivity at the different trophic levels and the peculiarities of their structure and function (Reichholf, 1980). They are outstanding consumers within this type of system (Martinez, 1993), playing an important role in the transfer of energy from these systems to terrestrial ones. They can obtain their food from different environmental units of the aquatic system by means of the spatial differential use of the environment or ecospace (Dobzhansky et al., 1983). Herons are also able to exploit resources throughout the year and at different hours of the day (Pianka, 1982; Martinez, 1993).

Many studies on the trophic ecology of herons, their association with habitats, food resources and feeding spectrum have been reported (Kushlan, 1976a, 


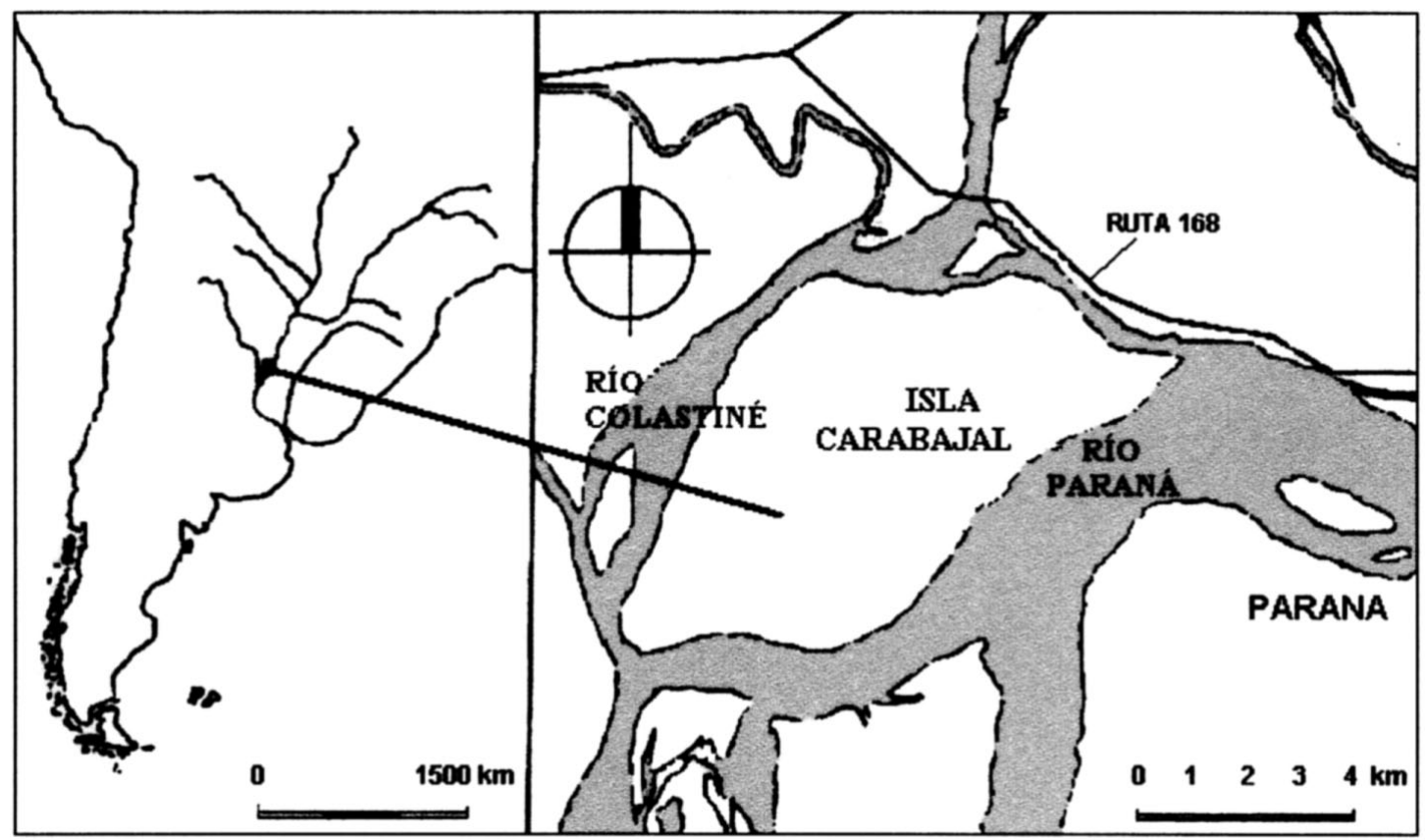

Figure 1 Geographical location of the Carabajal island, Province of Santa Fe, Argentina. (grey=water, white=land).

1976b, 1978, 1981; Amat and Soriguer, 1981; Amat, 1984; McNeil et al., 1993; Lekuona and Campos, 1995; Ntiamoa-Baidú et al., 1998). However, although the Cattle Egret is very common and occupies a large geographic area, little is known about its feeding activity, with the only available contributions being those of Zaccagnini and Beltzer (1982) in northern Argentina and Beltzer et al. (1987) in the area of the Paraná River. Like other ardeid species, such as Great Egret (Ardea alba), Cocoi Heron (Ardea COCoi) and Snowy Egret (Egretta thula), it is one of the most important components of the bird community associated with different environments of the middle Paraná River. Therefore, this study aims to present new results about the feeding ecology of the species in the valley of the Paraná River.

\section{METHODS}

Fieldwork was conducted on the Carabajal island, Santa Fe, northern Argentina $\left(31^{\circ} 39^{\prime} \mathrm{S}, 60^{\circ} 42^{\prime} \mathrm{W}\right)$ that has an area of about 4,000 ha (Figure 1). This island belongs to the geomorphologic unit called "plain of banks" (Iriondo and Drago, 1972). Numerous lenitic water bodies (stagnant waters) are found in this island, some of considerable extension such as ponds "La Cuarentena" (80 ha), "La Cacerola" (80 ha), "Vuelta de Irigoyen" (70 ha) and "El Puesto" (40 ha). For this study, and following the criteria proposed by Beltzer (1981, 1990a, 1990b, 1991), Neiff (1975, 1979, 1986a, 1986b) and Beltzer and Neiff (1992) for the flood valley of the Paraná River, the following units of vegetation and environment ("UVEs") have been recognised: open waters, floating and rooted aquatic vegetation, gallery forests, grasslands, pastures, beach and forest.

Thirty individuals captured with a firearm (16-gauge shotgun) and some few (seven out of 30) caught with mist nets between 1999 and 2002 were used. Stomach contents from the live birds were obtained by stomach washing following Emison (1968) and Cowan (1983). It operates by forcing water into the proventriculus through a plastic tube, after which birds were inverted, pressure applied to the stomach and aimed the bird at a container. For dead birds, the proventriculus was injected with $10 \%$ formalin (to stop digestive processes) while in the field and opened in the laboratory. All contents were fixed in $10 \%$ formalin for subsequent qualitative and quantitative analysis. The hour of capture and the weight of the birds and their stomachs were recorded. Field observations were also conducted to determine the habitats used and the hours of activity.

Once in the laboratory, stomach contents were analysed individually under a binocular magnifying glass, to identify and quantify the organisms at different levels of taxonomic resolution. In order to count organisms in advanced digestion state, the key structures or pieces such as heads, jaws, elytra, chelicerae, etc., were regarded as individuals.

The contribution of each prey item to the diet of the species was established by applying the index of relative importance (IRI; Pinkas et al., 1971):

$$
I R I=\% F O(\% N+\% V)
$$


Where $\% F O$ is the percentage frequency of occurrence of a particular category of food, $\% \mathrm{~N}$ is the percentage numerical and $\% \mathrm{~V}$ the percentage by volume (measured by water column displacement when all items from a single food category are introduced into a test tube).

Trophic diversity was determined following Hurtubia's criterion (1973) to calculate the diversity $(H)$ of prey for each individual using the formula of Brillouin (1965):

$$
H=(1 / N)\left(\log 2 N !-\sum \log 2 N i !\right)
$$

Where $N$ is the total number of organisms found in the stomach of each individual and $\mathrm{Ni}$ is the total number of preys $i$ in each stomach. The accumulated trophic diversity $(H k)$ was obtained by randomly adding trophic diversity's values $(H)$ per stomach. The asymptote (point t, p.t.) of the curve, that results of its graphic representation, allows us to determine the minimum sample size.

Dietary selectivity was evaluated applying the Spearman Rank Correlation, rs (Sokal and Rohlf, 1979; Schefler, 1981):

$$
r_{s}=1-\frac{6 \sum(X-Y)^{2}}{n\left(n^{2}-1\right)}
$$

where $X$ is the abundance range of prey found in the stomach, $Y$ is the abundance ordinal range of the prey in the study area, according a qualitative evaluation and $n$ is the number of species prey.

Feeding efficiency, $P e$, was estimated following Acosta Cruz et al. (1988) and calculated per each year's season:

$$
P e=\frac{1-x \text { p.cont } . \times 100}{x \text { p.corp. }}
$$

where $p$. cont. is the weight of the stomach contents (in g) and p.corp. is the weight of the body of birds (in g).

The trophic amplitude of the niche was calculated by means of the index of Levins (1968):

$$
N_{B}=\left(\sum P_{i j}^{2}\right)^{-1}
$$

where $P_{i j}$ is the probability of item $i$ in the sample $j$. It was calculated for each season to analyse the seasonal equivalent of the diet.

With the purpose of establishing the hourly rhythm of the feeding activity, the average satiety index was calculated, IF (Mean Index of Fullnes, Maule and Horton, 1984):

\begin{tabular}{|c|c|c|c|}
\hline Organism & $\mathrm{N}$ & OF & $\mathrm{H}$ \\
\hline \multicolumn{4}{|l|}{ Animals } \\
\hline \multicolumn{4}{|l|}{ Insecta } \\
\hline \multicolumn{4}{|l|}{ Orthoptera } \\
\hline \multicolumn{4}{|l|}{ Paulinidae } \\
\hline Marellia sp. & 35 & 24 & A \\
\hline Paulinia acuminata & 13 & 23 & A \\
\hline \multicolumn{4}{|l|}{ Lepismidae } \\
\hline Cornops aquaticum & 85 & 26 & A \\
\hline Acrididadae (Unidentified) & 29 & 15 & $\mathrm{~T}$ \\
\hline Orthoptera (Unidentified) & 12 & 21 & ? \\
\hline \multicolumn{4}{|l|}{ Gryllidae } \\
\hline Gryllodes sp. & 31 & 12 & $\mathrm{~T}$ \\
\hline \multicolumn{4}{|l|}{ Coleoptera } \\
\hline Hydrophilidae (Unidentified) & 10 & 8 & A \\
\hline Trotispernus sp. & 4 & 2 & A \\
\hline Dytiscidae (Unidentified) & 12 & 9 & A \\
\hline Curculionidae & 13 & 3 & A \\
\hline Unidentified & 2 & 1 & $?$ \\
\hline \multicolumn{4}{|l|}{ Hemiptera } \\
\hline \multicolumn{4}{|l|}{ Belostomidae } \\
\hline Belostoma sp. & 3 & 1 & A \\
\hline Lepidoptera (Unidentified larvae) & 1 & 1 & $?$ \\
\hline \multicolumn{4}{|l|}{ Arachnida } \\
\hline Pysauridae (Unidentified) & 41 & 13 & A \\
\hline \multicolumn{4}{|l|}{ Amphibia } \\
\hline \multicolumn{4}{|l|}{ Hyllidae } \\
\hline Hypsiboas pulchellus & 12 & 9 & A \\
\hline \multicolumn{4}{|l|}{ Plants } \\
\hline Unidentified seeds type A & 5 & 3 & ? \\
\hline Unidentified seeds type B & 1 & 1 & ? \\
\hline
\end{tabular}

$$
I F=\frac{S c \text { vol }}{B m}
$$

Table 1 Trophic spectrum of Cattle Egret

$\mathrm{N}$, Number of individuals from each food category; OF, frequency of occurrence of a particular food category; $\mathrm{H}$, Habitat type where food item is typically found ( $\mathrm{A}=$ aquatic; $\mathrm{T}=$ terrestrial; ?= unknown).

where $S c$ vol is the volume of the stomach contents (in $\mathrm{cm}^{3}$ ) and $B \mathrm{~m}$ is the body mass of the bird to each time interval of capture (in g).

Finally, the association of this species with different environments typical of the flood valley of the Paraná river was analysed by means of the index of habitat preference, $\mathrm{Pi}$ (Duncan, 1983).

$$
P i=\log / \mathrm{Vi} / \mathrm{Ai} /+1
$$

Where $V i$ is the percentage of individual recorded in each "UVEs" and $A i$ is the percentage of cover corresponding at each "UVEs". Following the criteria proposed by Bignal et al. (1988), values higher than 0.3 indicate a high preference for one specific "UVE" and values lower indicate a smaller preference.

\section{RESULTS}

All the stomachs analysed $(n=30)$ contained food. We recorded 17 taxa (Table 1), 88.24\% of which were animal remains (15 taxa) and the remaining $11.76 \%$ were plant remains (two taxa).

The application of the index of relative importance (IRI) yielded the following values: insects $=15,000$ 


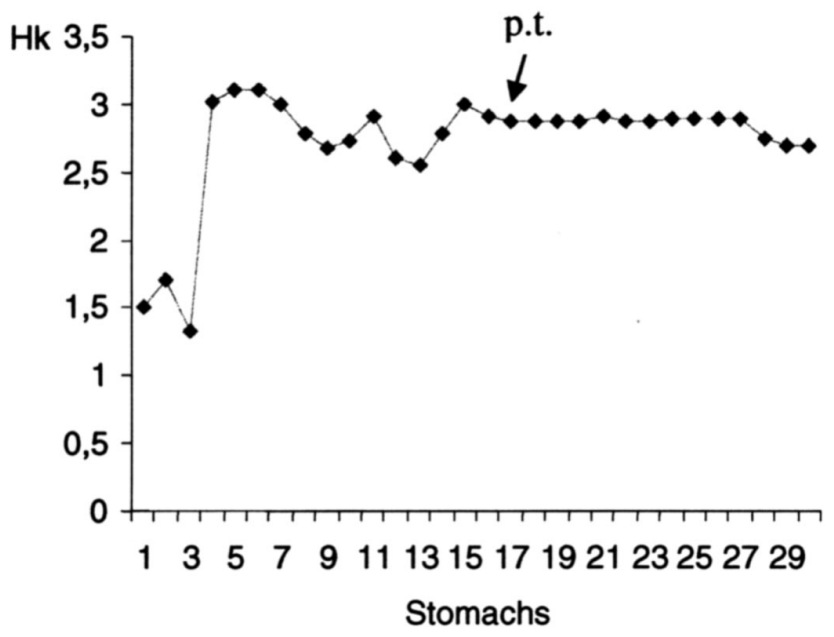

Figure 2 Accumulated trophic diversity $(\mathrm{Hk})$ for Cattle Egrets: the accumulated trophic diversity $(H k)$ was obtained by randomly adding trophic diversity's values $(H)$ per stomach. The asymptotic (point t, p.t.) of the curve, that results of its graphic representation, allows to determine the minimum sample size.

$(96 \%)$, arachnids $=250(2 \%)$ and amphibians $=250$ $(2 \%)$. Among the insects which constituted the main food, Orthoptera were predominant and mainly associated with vegetation (e.g. Marelia sp., Paulinia acuminata and Cornops aquaticum). For Coleoptera, beetles of the Hydrophilidae, Dytiscidae and Curculionidae prevailed. Arachnids and amphibians constituted secondary food categories, the former being represented by Pysauridae and the latter by Montevideo treefrog (Hypsiboas pulchellus).

The value of the reached p.t. indicates that the number of stomachs studied fits the statistical requirements of a minimum sample (Magurran, 1989). Diversity values for the stomach ranged between 1.03 and 2.76, being more frequent those included in the interval of average diversity. The accumulated trophic diversity was 2.7 and values allowed to reach the asymptote (p.t., Figure 2).

Prey ingested varied in size with the $21-30 \mathrm{~mm}$ size class being the most numerous, representing 45\% of the whole diet (Figure 3). Different species of Orthoptera were the predominant prey in this interval, whereas those of smaller size corresponded to beetles and those of greater size corresponded to amphibians and some belostomid bugs. Values corresponding to niche amplitude and feeding efficiency appear in Table 2. Dietary selectivity results, obtained by the

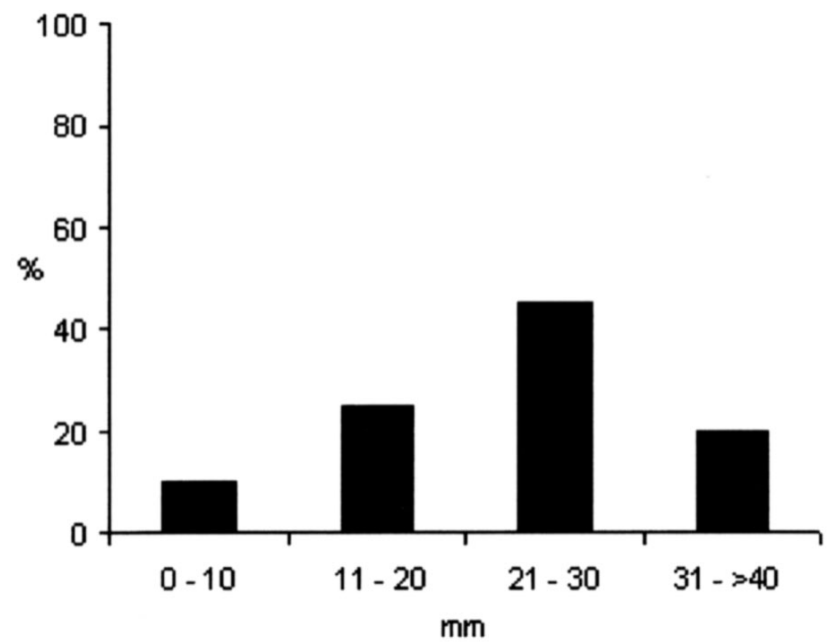

Figure 3 Size of the prey ingested by Cattle Egret expressed as a percentage of the number of prey ingested by size class.

calculation of Spearman Rank Correlation, was not significant $\left(\mathrm{r}_{\mathrm{s}}=0.84, P>0.001\right)$, indicating that the specie was not selective about any food items.

According to the IF values obtained, the Cattle Egret showed feeding activity following a bell-shaped model (Figure 4) with a characteristic peak at noon and a reduction at dusk. The species used three "UVEs": pastures, open waters and aquatic vegetation. The obtained values for the $\mathrm{Pi}$ were $0.34,0.13$ and 0.08 respectively, thus pastures being the most used.

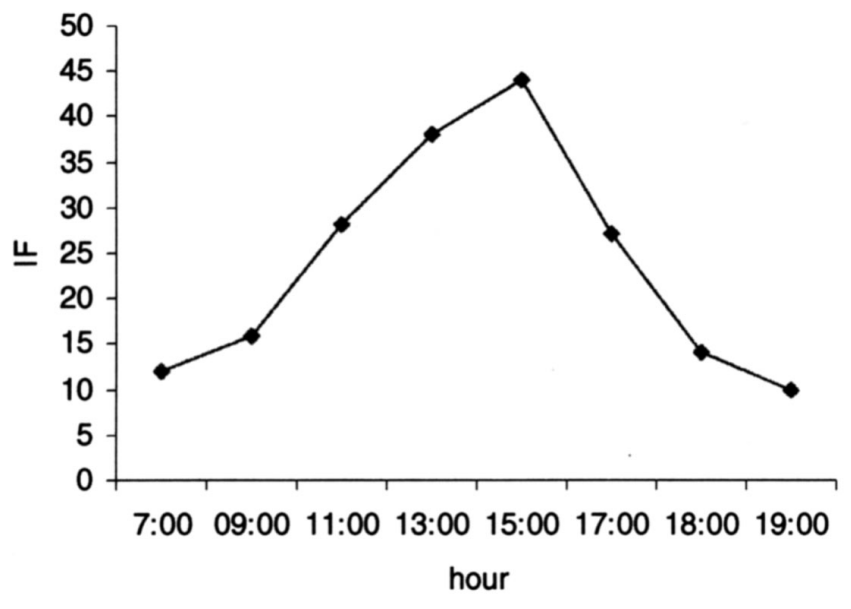

Figure 4 Rate of feeding activity for Cattle Egret calculated as the average satiety index (IF) for each time interval of capture.

Table 2 Niche amplitude and feeding efficiency throughout the season

\begin{tabular}{lcccc}
\hline & Spring & Summer & Autumn & Winter \\
\hline Dates & $21 / 9-20 / 12$ & $21 / 12-20 / 3$ & $21 / 3-20 / 6$ & $21 / 6-20 / 9$ \\
Niche amplitude & 3.45 & 2.09 & 1.98 & 2.01 \\
Feeding efficiency & $89.05 \%$ & $93.56 \%$ & $94.03 \%$ & $91.9 \%$ \\
\hline
\end{tabular}




\section{DISCUSSION}

Records about the Cattle Egret feeding activity in the study area are limited to general works in which only the large groups of organisms constituting the diet of the species are mentioned. The results of this study allow us to obtain greater accuracy regarding the taxonomic resolution of food. Insects represented the main food, while amphibians and arachnids were secondary categories. The results obtained basically agree with the information contributed by Bó and Darrieu (1993) according to which the diet of this heron is distinctly carnivorous, being $80 \%$ represented by invertebrates, mostly insects (orthopterous, coleopterous, dipterous and lepidopterous in decreasing abundance). There is also agreement on the fact that arachnids and amphibians represent a minor percentage of the food. These authors report reptiles (Anguidae) as constituents of the egret's diet but these were not observed in the present study.

Zaccagnini and Beltzer (1982) found a total of 25 taxonomic entities being insects the largest category, followed by amphibians, fish and arachnids. In the area of the Paraná River, Beltzer et al. (1987) found 11 taxonomic items highlighting the orthopterous as the largest followed by arachnids, amphibians and other insects. Others studies elsewhere in its area of distribution agreed that the diet of the species is basically composed by insects of the order Orthoptera (Fogarty and Hetrick, 1973; Amat and Soriguer, 1981; McKilligan, 1984). Siegfried (1971) observed in South Africa a similar importance of Lepidoptera and Orthoptera.

The values obtained in relation to the amplitude of the trophic niche would indicate similarity in feeding during summer, autumn and winter, although there is an increase in spring. These results may show certain seasonal changes in the availability of resources (though not quantified). Jenni (1973) also found that the diet of the species can vary according to season. Siegfried (1971) and Torres and Gutierrez (1999) reported that the Cattle Egret's diet varied temporarily depending on the abundance of prey and indirectly depending on rainfall at some times of the year. In the present study, the changes detected could be explained considering the increase in density of insects that occurs in the spring. Feeding efficiency values (that oscillated around 90\%) are concordant with Ricklefs (1998) who affirms that values between 60 and $90 \%$ correspond to predators that consume food of animal origin.

Dietary selectivity was not significant, thus showing that the Cattle Egret has a high degree of plasticity in its diet. This results coincide with those of others (Siegfried, 1971; Fogarty and Hetrick, 1973; Jenni,
1973; Amat and Soriguer, 1981; McKilligan, 1984) who mention that the Cattle Egret, like other herons, is an opportunistic predator, and for that reason its diet could change widely according to the environmental conditions and supply of resources. In relation to the circadian rhythm of food, Custer and Osborn (1978) and Seedikkoya et al. (2005) found a similar pattern: a diurnal feeding activity with only a peak in activity at noon and a reduction at dusk.

According to Szijj (1965), usage of a particular habitat will be a function of, amongst other factors, food availability and accessibility. In agreement with this concept, the Cattle Egret demonstrated a differential use of pastures where food is obtained more easily. The preference for this type of environment is a characteristic feature of the basically insectivorous species. Seedikkoya et al. (2005) noted that this species also showed a differential use of the same habitats, grass fields being the most frequently used.

Based on the fact that the Cattle Egret can be considered a relatively new species in the flood valley of the Paraná River (as in other regions of the world), the impact that its presence generates in the newly occupied environments should be of particular interest to obtain a better knowledge of the conservation of this species and the aquatic systems.

Torres and Gutierrez (1999) found in their work that adults of Cattle Egret feed the chicks with a diet based mainly of insects and affirm that for this reason the species constituted important crop pests control agent in the studied area. In others studies, herons were seen to prey upon cattle ectoparasites (Kaufman, 1996; Seedikkoya, 2005). Whether Cattle Egrets play a similar role in pest control in the study area requires further research.

Furthermore, we believe that it is also important to understand the interactions of Cattle Egret with native species of heron. It is our intention that the results of this work can be used as the basis for future studies that are addressed with this aim. Weber (1972) argues that the diet of Cattle Egret, basically insectivorous, does not overlap with the diet of native herons, which eat mainly fish and aquatic invertebrates. A similar conclusion could be proposed in this work because Beltzer (2007) found in the flood valley of the Paraná River that the fish represent the main food of most of the native herons (e.g. Great Egret and Cocoi Heron). In this sense, we could say that this differentiation in diets of these species could be considered as a mechanism for allowing their coexistence.

Although some species of herons also eat mainly at noon (like the Cattle Egret) others eat all day, show two peaks of feeding activity, or eat especially in the evening and night (Beltzer, 2007). These differences 
in the circadian rhythm of feeding activity could also be interpreted as a mechanism of segregation.

The hydrological regime of the Paraná River determines the existence of variations in the environmental units and, as a result, the presence of spatial heterogeneity (Beltzer and Neif, 1992). The herons used several "UVEs", although choose some more frequently depending on their food requirements. So the aquatic vegetation would be the nuclear area for herons which eat principally fish, and pasture would be favoured by the basically insectivorous like the Cattle Egret (Beltzer, 2007). This differential use of habitat could be seen as another mechanism of isolation.

Considering a mainly insectivorous diet and the ecological features previously stated and according to Weber (1972) and Kaufman (1996), we can say the Cattle Egret would have little impact on any particular species and that should be classified as a beneficial addition to the native fauna.

\section{REFERENCES}

Acosta Cruz, M., Torres, O. and Mugica Valdés, L. (1988) Subnicho trófico de Dendrocygna bicolor (Vieillot) (Aves: Anatidae) en dos arroceras de Cuba. Cienc. Biol., 19-20, $41-50$.

Amat, J.A. (1984) Las poblaciones de aves acuáticas en las lagunas andaluzas. Composición y diversidad durante un ciclo anual. Ardeola, 31, 61-79.

Amat, J.A. and Soriguer, R.C. (1981) Alimentación primaveral de la garcita bueyera. Doñ. Acta Vertebr., 8, 207-213.

Beltzer, A.H. (1981) Nota sobre fidelidad y participación trófica de Egretta alba egretta (Gmelin, 1789) y Egretta thula thula (Molina 1782) en ambientes del río Paraná medio (Ciconiiformes, Ardeidae). Rev. Assoc. Cienc. Nat. Litoral., 12, 136139.

Beltzer, A.H. (1990a) Notes on the food of the Rufescents Tiger Heron Tigrisoma lineatum (Aves: Ardeidae) in the Middle Paraná River Floodplain, Argentina. Stud. Neotrop. Fauna Envir., 25, 93-96.

Beltzer, A.H. (1990b) Biología alimentaria del gavilán común Buteo magnirostris (Aves: Accipitridae) en el valle aluvial del río Paraná medio, Argentina. Ornitol. Neotrop., 1, $1-$ 7.

Beltzer, A.H. (1991) Aspects of the breeding biology and the death rate of the Butorides striatus (Aves: Ardeidae). Rev. Assoc. Cienc. Nat. Litoral., 22, 35-40.

Beltzer, A.H. (2007) Relaciones tróficas y mecanismos de segregación ecológica entre las especies de garzas del valle de inundación del río Paraná (AVES: ARDEIDAE). PhD Thesis, Universidad Nacional de La Plata, Facultad de Ciencias Naturales y Museo.

Beltzer, A.H. and Neiff, J.J. (1992) Distribución de las aves en el valle del río Paraná. Relación con el régimen pulsátil y la vegetación. Amb. Subtrop., 2, 77-102.
Beltzer, A.H., de Carlo de Ara, E.B., Mosso, E.D. and Rosa de Montaner, A.Y. (1987) Alimentación otoñal, anatomía macroscópica e histológica del tubo digestivo de la garcita bueyera Bubulcus ibis ibis (Aves: Ardeidae). Rev. Assoc. Cienc. Nat. Litoral., 18, 155-186.

Bignal, E.M., Curtis, D.J. and Matthews, J.L. (1988) Islau land types. Bird habitats and nature conservation. Part. 1: Land use and birds on Islay. NCC Chief Scientist Directorate, 809.

Bó, N.A. and Darrieu C.A. (1993) Aves ciconiformes; ardeidae, ciconiidae. Fauna de agua dulce de la República Argentina, Vol. 43.1B.

Brillouin, I. (1965) Science and information theory. Academic Press, New York.

Cowan, A.N. (1983) A modified penguin stomach tube. Corella, 7, 59-61.

Custer, T.W. and Osborn R.C. (1978) Feeding habitat use by colonially-breeding herons, egrets, and ibises in North Carolina. Auk, 95, 733-743.

de la Peña, M.R. (1992) Guía de Aves Argentinas. No. 1: Rheiformes-Tinamiformes-Sphenisciformes-Podicipediformes-Procellariiformes-Pelecaniformes-ArdeiformesPhoenicopteriformes-Anseriformes, 2nd edn. L.O.L.A., Santa Fe, Argentina.

Dodzhansky, T., Ayala, F., Stebbins, G.L. and Valentine J.W. (1983) Evolución. Omega, Barcelona, Spain.

Duncan, P. (1983). Determination of the use of habitat by horses in Mediterranean wetland. J. Anim. Ecol., 52, 93-109.

Emison, W.B. (1968) Feeding preferences of the Adelie Penguin at Cape Crozier, Ross Island. In: Austin, I.O. Jr, (ed.), Antarctic bird studies. Antarct. Res. Ser., 12, $191-$ 212.

Fogarty, M.J. and Hetrick, W.M. (1973) Summer foods of Cattle Egret in North Central Florida. Auk, 90, 268-280.

Heatwole, H. (1965) Some aspects of the association of Cattle Egrets with cattle. Anim. Behav., 13, 79-83.

Hurtubia, J. (1973) Trophic diversity measurement in sympatric species. Ecology, 54, 885-890.

Iriondo, M. and Drago, E.C. (1972) Descripción cuantitativa de dos unidades geomorfológicas de la Ilanura aluvial del Paraná medio, República Argentina. Rev. Assoc. Geol. Arg., 27, 143-154.

Jenni, D.A. (1973) Regional variation in the food of Nestling Cattle Egrets. Auk, 90, 821-826.

Kaufman, K. (1996) Lives of North American birds. Houghton Mifflin Company, Boston.

Kushlan, J.A. (1976a) Wading bird predation in seasonally fluctuating pon. Auk, 93, 464-476.

Kushlan, J.A. (1976b) Feeding behavior of North American Herons. Auk, 93, 86-94.

Kushlan, J.A. (1978) Nonrigorous foraging by Robbing Egrets. Ecology, 59, 649-653.

Kushlan, J.A. (1981) Resource use strategies of wading birds. Wilson Bull., 93, 145-163.

Lekuona, J.M. and Campos F. (1995). Le succès de reproduction du Héron cendré (Ardea cinerea) dans le Bassin d'Arcachon. Alauda, 63, 179-183.

Levins, R. (1968) Evolution in changing environment. Princeton, New Jersey.

Magurran, A.E. (1989) La diversidad ecológica y su medición. Vedra, Barcelona, Spain. 
Martínez, M. (1993) Las aves y la limnología. Conferencias de limnología, pp. 127-140. La Plata, Argentina.

Maule, A.G. and Horton H.F. (1984) Feeding ecology of walleye Sttizostedion vitreun viterun in the MidColumbia river, with emphasis on the interaction between valley and juvenile anadromous fishes. Fish Bull., 82, $411-$ 416.

McKilligan, N.G. (1984) The food and feeding ecology of the Cattle Egret Ardeola ibis in Guyana, South America. Ibis, 109, 168-179.

McNeil, R., Drapeau, P. and Pierotti, R. (1993) Nocturnality in colonial waterbirds: occurrence special adaptations and suspected benefits. Curr. Ornithol., 10, 187-246.

Neiff, J.J. (1975) Fluctuaciones anuales en la composición fitocenótica y biomasa de la hidrofitia en lagunas isleñas del Paraná medio. Ecosur., 2, 153-183.

Neiff, J.J. (1979) Fluctuaciones de la vegetación acuática en ambientes del valle de inundación del Paraná medio. Phys. Sec. B, 38, 41-43.

Neiff, J.J. (1986a) Las grandes unidades de vegetación y los ambientes insulares del río Paraná en su tramo CandelariaItá Ibaté. Rev. Asoc. Cienc. Nat. Litoral., 17, 7-30.

Neiff, J.J. (1986b) Aspectos metodológicos y conceptuales para el conocimiento de las áreas anegables del Chaco Oriental. Ambiente Subtropical, 1, 1-4.

Ntiamoa-Baidú, Y., Piersma, T., Wiersma, P., Poot, M., Batley, P. and Gordon, C. (1998) Habitat selection, daily foraging routines and diet of waterbirds in coatal lagoon in Ghana. Ibis, 140, 89-103.

Petracci, P.F. and Delhey, K. (2005) Guía de las Aves Marinas y Costeras de la Ría de Bahía Blanca, 1st edn. P. Petracci, Bahía Blanca, Argentina.

Pianka, E.R. (1982) Ecología evolutiva. Omega, Barcelona, Spain.
Pinkas, L., Oliphant, M.S. and Iverson, Z.L. (1971) Food habits of albacore bluefin tuna and bonito in California waters. Dept. Fish Game, Fish Bull., 152, 1-105.

Rand, A.L. (1954) Social feeding behaviour of birds. Fieldiana Zool., 36, 1-71.

Reichholf, J. (1980) The consumer function of water birds in an aquatic ecosystem. Stenciled abstract of paper presented at the Symposium on Feeding Ecology of Waterfowl (IWRB), Gwatt, 1977.

Ricklefs, R.E. (1998) Invitación a la ecología. Economía de la naturaleza. Médica Panamericana, Buenos Aires, Argentina.

Schefler, W.C. (1981) Bioestadística. Fondo Educativo Interameriecano, México.

Seedikkoya, K., Azeez, P.A. and Shukkur, E.A.A. (2005). Cattle Egret Bubulcus ibis habitat use and association with cattle. Forktail, 21, 174-176.

Siegfried, W.R. (1971) The food of the Cattle Egret. J. Appl. Ecol., 8, 447-468.

Sokal, R.R. and Rohlf, F.J. (1979) Biometría. Principios y métodos estadísticos en la investigación biológica. Blume, Madrid, Spain.

Szijj, J. (1965). Biologische Untersuchungen an Entenvogeln (Anatidae) des Ermatinger Beckens (Bodensee). Vogelwarte, 23, 24-71.

Torres, R. and Gutiérrez, M. (1999) Dieta de los pichones de la Garcita Bueyera (Bubulcus ibis) en la Laguna Mar Chiquita (Córdoba, Argentina). Natura Noetropicallis, 30, 35-41.

Weber, W.J. (1972) A new world for the cattle egret. Nat. Hist., 81, 56-63.

Zaccagnini, M.E. and Beltzer, A.H. (1982) Alimentación de Bubulcus ibis ibis L. 1758 y su relación trófica con Egretta thula thula (Molina, 1782) en Leales (Tucumán) (Ciconiiformes: Ardeidae). Rev. Asoc. Cienc. Nat. Litoral., 13, $73-$ 80. 